\title{
Benthic-pelagic flux rates on mussel beds: tunnel and tidal flume methodology compared
}

\author{
H. Asmus ${ }^{1}$, R. M. Asmus ${ }^{1}$, T. C. Prins ${ }^{2}$, N. Dankers ${ }^{3}$, G. Francés ${ }^{1}$, \\ B. $M a a \beta^{1} \&$ K. Reise ${ }^{1}$ \\ ${ }^{1}$ Biologische Anstalt Helgoland, Wattenmeerstation Sylt; D-W-2282 List, \\ Federal Republic of Germany \\ ${ }^{2}$ Nederlands Instituut voor Oecologisch Onderzoek; Centrum voor Estuariene en \\ Mariene Oecologie, Vierstraat 28, NL-4401 EA Yerseke, The Netherlands \\ ${ }^{3}$ Institute for Forestry and Nature Research (IBN-DLO); P.O. Box 167, NL-1790 AD Den \\ Burg, Texel, The Netherlands
}

\begin{abstract}
Material flux rates in an intertidal mussel bed were measured synchronously over two tidal cycles in June 1989 with Benthic Ecosystem Tunnels and a double lane flume. The tunnels enclosed the near bottom water, whereas the flume canalized the total water column. One tunnel was set up in a mussel bed and another one in an adjacent sand bottom as a control. The flume enclosed a mussel lane and a sand lane. In the tunnel and in the flume the mussel bed revealed ammonium and phosphate discharge. At the same time, phytoplankton, dominated by Phyaeocystis globosa, was taken up intensively. These flux rates showed the same tendency but they were higher in the flume than in the tunnel. Different tendencies and flux rates for oxygen and particulate organic matter (POC, PN) were found in flume and tunnel. These differences demonstrate the importance of water column processes regarding the material exchange of a mussel bed. Tunnels enclose smaller bodies of water and are therefore expected to detect even small effects of the benthos on the passing water. In flumes, benthic influence may be diluted over the entire water column but conditions are more natural. The use of flumes is restricted to shallow waters while tunnels have the potential to be used at any depth.
\end{abstract}

\section{INTRODUCTION}

Dense assemblages of suspension-feeding bivalves exchange extremely high amounts of particulate matter, nutrients and oxygen with the overlying water (Murphy \& Kremer, 1985; Doering et al., 1987; Dame \& Dankers, 1988; Dame et al., 1989; Dame et al., 1991; Dankers et al., 1989; Prins \& Smaal, 1990; Asmus et al., 1990). They constitute key structures for the material flux in shallow water habitats (Asmus \& Asmus, 1990). To measure these benthic-pelagic flux rates directly, it is necessary to confine tidal waters so that they flow over a prescribed area. Water samples are taken upstream and downstream of this area, when the water has passed through it (Nixon et al., 1971). Differences in material concentrations occurring during this horizontal flow of water are recalculated into vertical flux rates by taking into account the size of the area and the amount of water flow. Previously, tunnels which enclosed the near bottom water (Dame et al., 1984) and 
flumes which merely prevented the lateral flow of water (Wolaver et al., 1985) were in use independently to quantify the material fluxes. In this study, the two methods are compared directly. The volume of water flowing through a tunnel per time unit is relatively small. Thus, it can be expected that even small effects of the benthos on the passing water can be detected. The water mass flowing through a flume includes the upper part of the water column. The relation of water volume to bottom area is higher than in the tunnel. Small fluxes between sediment and water column may lead to insignificant concentration differences between inflow and outflow as a consequence of dilution over the entire water column, but the natural conditions are hardly altered and a circulation of particulate matter in the water column is not interrupted. The use of flumes is restricted to shallow waters while tunnels have the potential to be used at any depth. Differences in the results between tunnels and flumes may both reflect methodological differences and elucidate the influence that the total water column has on the benthic exchange.

\section{MATERIAL AND METHODS}

\section{Study site}

The experiments were carried out in the Wadden Sea near the island of Sylt (eastern North Sea). The intercalibration of tunnel and flume measurements was made during one tidal cycle by day ( 1 June 1989) and one at night ( 2 to 3 June). Mussel beds (Mytilus edulis L.) occur around low tide level, forming a belt of 50 to $100 \mathrm{~m}$ in width in the outer Königshafen. Macrozoobenthic biomass ( $2800 \mathrm{~g}$ ash free dry weight $\mathrm{m}^{-2}$ ) was dominated by $M$. edulis $\left(92 \%, 2576 \mathrm{~g} \mathrm{AFDW} \mathrm{m}^{-2}, 5115\right.$ mussels per $\left.\mathrm{m}^{2}\right)$. The tidal flow approaches the area from a southeastern direction. Turbidity as well as current velocity are strongly affected by wind. Tidal range and average depth at high tide is $1.8 \mathrm{~m}$. Mussels are flooded for $8-10 \mathrm{~h}$ and are exposed for 2-4 h during one tidal cycle. The salinity of the water is 28 to $32 \%$.

\section{Benthic Ecosystem Tunnel}

The Benthic Ecosystem Tunnel was developed by Dame et al. (1984) to quantify material flux on an intertidal oyster reef. In this study, two tunnels were used which have the same dimensions (Fig. 1). The tunnels are made of Plexiglass plates, joined together by neoprene strips. The tunnels have a total length of $10 \mathrm{~m}$ between the sampling points, a width of $0.8 \mathrm{~m}$, a cross-sectional area of $0.225 \mathrm{~m}^{2}$ and cover $7.9 \mathrm{~m}^{2}$ of sediment. The tunnels have been used before for studies on mussel beds in the Dutch Wadden Sea (Dame \& Dankers, 1988; Dankers et al., 1989) and the Oosterschelde estuary (Prins \& Smaal, 1990). At current speeds higher than $1 \mathrm{~cm} \mathrm{~s}^{-1}$, a turbulent mixing of the water flowing through the tunnels occurs.

Two tunnels were used in the experiment. One was placed over a mussel bed alongside the flume, the other was placed on bare sediment near the mussel tunnel (Fig. 1). The tunnels were placed in the direction of the ebb and flood current. The sand tunnel served as a control. Water samples from the in-and outflow of the tunnels were collected with battery driven pumps from a platform on top of the adjacent flume. 


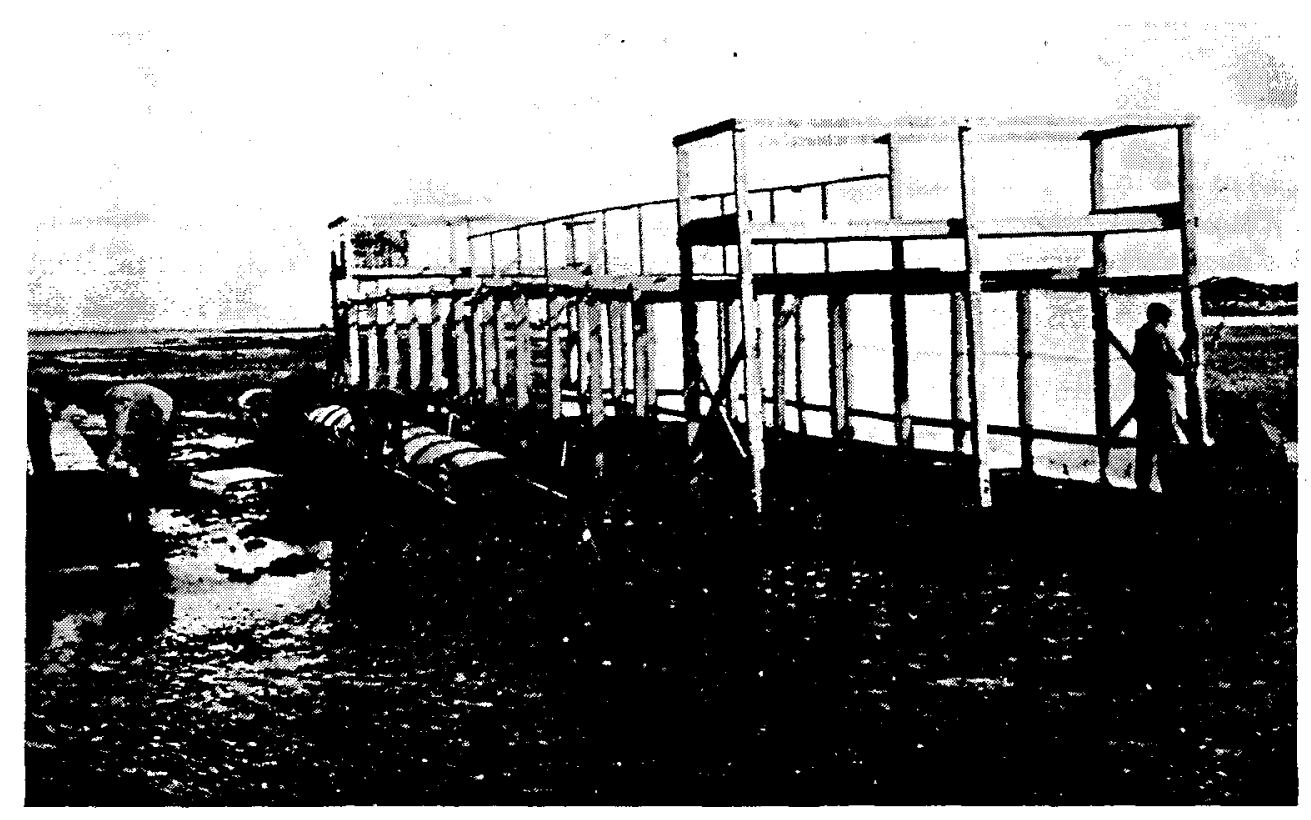

Fig. 1. Set up of benthic ecosystem tunnel compartments (in total $10 \times 0.8 \mathrm{~m}$ ) on a mussel bed and an adjacent sand area (left side), and the Sylt flume $(20 \times 4 \times 2 \mathrm{~m})$ with a mussel lane and a sand lane.

One plastic foil has just been fastened

\section{Sylt flume}

The technique of the Sylt flume has been described in earlier publications (Asmus et al., 1990; Asmus \& Asmus, 1991). This former single lane version of the flume could be improved by constructing a double flume which allowed the synchronous measurement of exchange processes over a mussel bed and over a control area free of mussels (Fig. 1). The Sylt flume consists of a wooden frame system $20 \mathrm{~m}$ in length, $4 \mathrm{~m}$ in width and $2 \mathrm{~m}$ in height. The flume was placed on an intertidal mussel bed parallel to the main current direction. On the two outer walls and in the middle of the flume, plastic foils were fastened to canalize tidal waters and to prevent lateral mixing. Heavy iron chains pressed the lower margin of these foils to the bottom. These plastic foils border two lanes. In one lane the mussel bed remained undisturbed, in the other lane all mussels were removed 4 weeks before the experiment, and only the bare sediment was left. This lane worked as a control lane. At each end of the flume, a platform was built for scientists and equipment which stayed there throughout inundation time. Both platforms were connected by a small footbridge. Water samples from the in- and outflow of the flume were collected with battery driven pumps anchored $20 \mathrm{~cm}$ above the bottom. When the water level exceeded $0.8 \mathrm{~m}$ (mid-tide level), additional samples were taken from the surface by drifting pumps. 


\section{Sampling procedure}

During rising tide, the first samples were taken synchronously from both tunnels and flume lanes at the platform where the water entered. Simultaneously, a buoy was released into the flume drifting below the surface of both lanes. Additionally, current velocity was measured by induction current meters (Marsh McBirney, NSW Meerestechnik) in the flume and in the tunnels. Residence time of water in the flume was indicated by the time interval the buoys drifted between the two platforms. In the tunnels, residence time was calculated from current speed, measured continuously. The moment the water passed the flume or the tunnels, the second set of samples was taken at the outflow. Also oxygen was measured at inflow and outflow. Duplicate samples were taken for the analysis of POC and PN. The samples were immediately transported to the laboratory by rubber dinghy. Samples were instantaneously analysed for nutrients (phosphate, ammonium), and filtered for measurements of POC, PN. The sampling procedure was repeated for each of the 4 measuring systems (mussel lane and sand lane of the flume, mussel tunnel and sand tunnel) 4 to 5 times per tidal cycle.

\section{Current velocity measurement}

Current velocity in the tunnels was measured by flowmeters installed in the centre of the tunnels (mussel tunnel: Marsh McBirney 201M induction flow meter, control tunnel: NSW Meerestechnik induction flow meter).

In the flume, 2 methods were used to measure the residence time of the water mass. Drifting buoys gave an integrated value of the current velocity for the time interval between the inflow sampling and outflow sampling. Thus, small alterations of current velocity within this sampling interval were included. Drifting buoys indicated only the current velocity at the water surface. Current velocity showed slight alterations with depth. In order to consider this, a current velocity profile was measured in the centre of the flume with a flowmeter (Marsh McBirney, 201). For measurements at the surface, both methods were correlated by a linear regression of $y=0.72+0.88 x, x=$ current velocity $\left(\mathrm{cm} \mathrm{s}^{-1}\right)$ measured with induction flow meter, $y=$ current velocity measured with drifting buoys, $r=0.92, n=9$. The correlation between the surface velocity of drifting buoys and the current velocity near the bottom is a linear regression of $y=0.86+0.96 x$, $\mathrm{r}=0.92, \mathrm{n}=9$. The maximal difference between the current velocity at the surface measured by drifting buoys and the current velocity near the bottom measured with the flowmeter is $<3 \mathrm{~cm} \mathrm{~s}^{-1}$. Current velocity was in the range of 1 to $12 \mathrm{~cm} \mathrm{~s}^{-1}$.

\section{Oxygen measurement}

Oxygen concentration in the tunnels was measured with continuously recording oxygen analysers (Yellow springs type no. 5739). Oxygen concentration in the flowing water of the flume was measured by 2 battery operated analysers (Chemograph, WTW) with electrodes at the inflow and outflow of the flume. In the sand lane, oxygen was measured using a transportable oxygen analyser (WTW, Microprocessor, Oximeter 196). All oxygen electrodes were equipped with a thermistor and battery operated stirrer, providing a continuous flow of at least $15 \mathrm{~cm} \mathrm{~s}^{-1}$ at the membrane surface. All electrodes 
were calibrated in the same calibration medium in order to minimize instrumental divergences. Oxygen electrodes were calibrated in oxygenated seawater $(100 \%$ saturation) and in $3 \% \mathrm{Na}_{2} \mathrm{SO}_{3}$ solution ( $0 \%$ saturation). Saturation values were converted into ppm using the oxygen temperature table by Wagner $(1979 a$ a b). Oxygen concentration was corrected for atmospheric pressure and salinity according to the Oceanographic Tables, Unesco (1973).

\section{Nutrient analysis}

Nutrient analysis included ammonium and inorganic phosphate. Nutrient analysis was performed after Grasshoff et al. (1983), using unfiltered samples (2 parallels, $5 \mathrm{ml}$ sample volume). When turbidity was high, samples were centrifuged prior to analysis. Analysis of samples started about half an hour after collection. The error in nutrient analysis was about $\pm 5 \%$.

\section{Seston analysis}

For seston analysis, 200 to $500 \mathrm{ml}$ of sample volume were filtered within 1 hour after collection through pre-ashed and weighed Whatman GF/glass-fibre filters. The filtered material was washed with distilled water in order to remove salt. Filters were dried at $60^{\circ} \mathrm{C}$ and weighed on an analytical microbalance. Particulate organic carbon and nitrogen were determined in an Elemental analyser (Carlo Erba, NA 1500). Before elemental analysis, the seston sample was kept in $\mathrm{HCl}$ vapour for $24 \mathrm{~h}$ to remove the carbonate fraction of the material. Then the filters were transferred to small tin containers which were loaded into an automatic sampler of the elemental analyser. Empty filters served as blanks. For calibration the tin containers were filled with 0.5 to $1 \mathrm{mg}$ acetanilide as a standard containing $10.36 \% \mathrm{~N}$ and $71.09 \% \mathrm{C}$. The tin containers fell one by one into the pyrolysis reactor where they were burned at a temperature of $1021{ }^{\circ} \mathrm{C}$. Analysis of each sample needed $420 \mathrm{~s}$. The sample amount of 3 to $22 \mathrm{mg}$ dry weight showed a range of 0.2 to $0.6 \%$ for $\mathrm{N}$ and a range of 1.5 to $5 \%$ for $\mathrm{C}$. The accuracy of this method was $\pm 5 \%$ for $\mathrm{N}$ and \pm 1.5 to $\pm 5 \%$ for $\mathrm{C}$ in relation to absolute values.

\section{Phytoplankton cell counting and calculation of biomass}

Phytoplankton cell counts and biomass calculations were carried out following the recommendations by Edler (1979). The samples were preserved with Lugol's iodine solution, stored in a cold dark room. After being gently shaken, the samples were filled into $25 \mathrm{ml}$ settling chambers. After settling, the cells were counted with an inverted microscope (Zeiss) at magnification of 100 up to 400 fold. Within 6 months, all cell counting had been completed. Because of the dense bloom of Phaeocystis globosa on 1st June, this species could only be counted in 5 fields of view at a magnification of $400 \times$ (up to 900 counted cells). Cells of less abundant species were counted in larger parts of the counting chamber (up to $1 / 2$ the area). Due to the difficulties in counting a $P$. globosa bloom, the error of total cell numbers per liter is assumed to be $\pm 10 \%$. Biomass of phytoplankton was calculated in carbon units on the basis of cell and plasma volume (Edler, 1979). 


\section{Calculation of clearance rate}

Clearance rates are defined as the volume of water swept clear of particles per unit time (Bayne, 1976). Clearance rates were estimated from the difference between input and output concentrations of particles. Assuming an equal distribution of the mussels in tunnel or flume, a constant filtration rate, complete mixing of the water, and no natural sedimentation or resuspension, the concentration of particles in the water flowing through the tunnel or flume decreases exponentially:

$$
C_{t}=C_{0} \cdot e^{-\frac{C R_{\text {mussel bed }} \cdot A \cdot t}{V o l}}
$$

(Coughlan, 1969)

$\mathrm{C}_{\mathrm{t}}$ : particle concentration at the end of tunnel or flume, $\mathrm{C}_{0}$ : particle concentration at the entrance of tunnel or flume, $\mathrm{CR}_{\text {mussel bed }}$ clearance rate of the mussel bed, $\mathrm{A}$ : surface area of the mussel bed $\left(\mathrm{m}^{2}\right)$ in tunnel or flume, $t$ : residence time of water in tunnel or flume (in h), Vol: water volume in tunnel or flume (in $\mathrm{m}^{3}$ ). Thus, the clearance rate of the mussel bed can be calculated from:

$$
\mathrm{CR}_{\text {mussel bed }}=\ln \left(\frac{\mathrm{C}_{0}}{\mathrm{C}_{\mathrm{t}}}\right) \cdot \frac{\mathrm{Vol}}{\mathrm{t}} \cdot \frac{1}{\mathrm{~A}} \text { in } \mathrm{m}^{3} \mathrm{~m}^{-2} \mathrm{~h}^{-1}
$$

\section{Calculation of flux rates}

\section{Tunnel}

The fluxes were calculated from the concentration differences between inflow and outflow and the water fluxes over the enclosed benthic area (mussel bed e.g. sand area). These water fluxes through the tunnels were calculated from current speed, considering the dimensions of the tunnels (Dame \& Dankers, 1988; Prins \& Smaal, 1990).

\section{Flume}

Concentrations of the different parameters (oxygen, nutrients and particles) were measured in the inflowing water and in the same water body when flowing out of the flume. These values were integrated over the whole water column, taking into account the varying tidal depth. The difference in the amount integrated over the total water column in the inflowing and outflowing water body is divided by the passage time in hours through the flume as determined by the combination of drifting buoy and current meter.

\section{RESULTS}

\section{Current speed}

A special feature of the study site is that the currents are highest during high tide (about $10 \mathrm{~cm} \mathrm{sec}-1$ ) and lowest during the end of ebb tide (about 2 to $1 \mathrm{~cm} \mathrm{sec}-1$ ). Reversal of current direction takes place for only a short time during low tide in the deeper gullies.

In the flume, current velocity was similar in the mussel lane and sand lane (Table 1). The range of current speed in the sand tunnel was comparable with those in both flume 
Table 1. Range of current speeds in tunnels and the Sylt flume during 2 periods of inundation

\begin{tabular}{|lll|}
\hline & \multicolumn{3}{c|}{$\begin{array}{c}\text { Range of current speed } \\
\left(\mathrm{cm} \mathrm{sec}^{-1}\right)\end{array}$} & $2-3$ June \\
\hline & 1 June & 3 \\
Mussel tunnel & $2-4$ & $2.8-7.3$ \\
Sand tunnel & $2-8.5$ & $2-11$ \\
Sylt flume: & $1-8$ & $3-12$ \\
Mussel lane & $1-9.5$ & \\
Sand lane & & \\
\hline
\end{tabular}

lanes at daytime. At night the current speed was lower. In the mussel tunnel, current velocity was distinctly reduced, especially around high tide.

\section{Oxygen}

Differences in oxygen changes were more pronounced between tunnels and flume than between mussel bed and sand areas (Table 3).

In the mussel tunnel, oxygen was consumed by day and at night at similar rates (Figs $2,3)$. In the sand tunnel there was no oxygen consumption by day and one rate of oxygen production at midday probably due to microalgal photosynthesis. At night, the oxygen consumption in the sand tunnel was similar to that in the mussel tunnel (Fig. 3).

In the mussel lane and in the sand lane of the flume, oxygen was produced by day (Fig. 2). This oxygen production was higher over sand than over mussels. The difference between both reveals the oxygen consumption of the enclosed mussel bed (Fig. 4).

During the night, respiration was high over mussels and sand in the flume except for the last rate (Fig. 3). Oxygen consumption was higher in the mussel lane than in the sand lane. A comparison shows that the oxygen consumption in the mussel tunnel was lower than the calculated oxygen consumption by the mussel bed in the flume (Wilcoxon matched pairs signed rank test, two sided, $\mathrm{P}<0.05, \mathrm{n}=7$ ).

\section{Ammonium}

High release of ammonium by the mussel bed was measured both in tunnel and flume by day and at night (Figs 5,6 ) (outflow concentrations are higher than inflow concentrations, Wilcoxon matched pairs test, one sided, tunnel: $\mathrm{P}<0.01$, flume: $\mathrm{P}<0.05$ ).

The release rates were higher in the flume than in the tunnel but differences were not statistically significant (Table 3). In the mussel lane of the flume, one uptake of ammonium was observed at midday. This may have been caused by the intense phytoplankton bloom. The mussel tunnel and mussel lane of the flume showed a significantly higher ammonium release than both controls (same test, one sided, $\mathrm{P}<0.05$, $\mathrm{n}=8$ ).

In the sand tunnel and in the sand lane of the flume, the ammonium flux rates were not significant and varied between release and uptake without showing a clear pattern. 

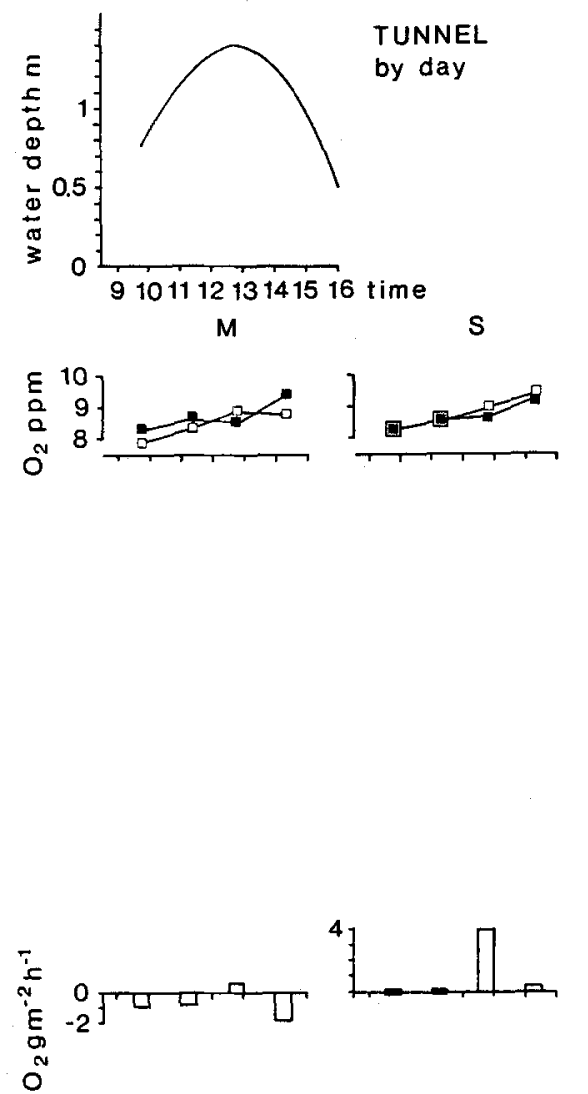
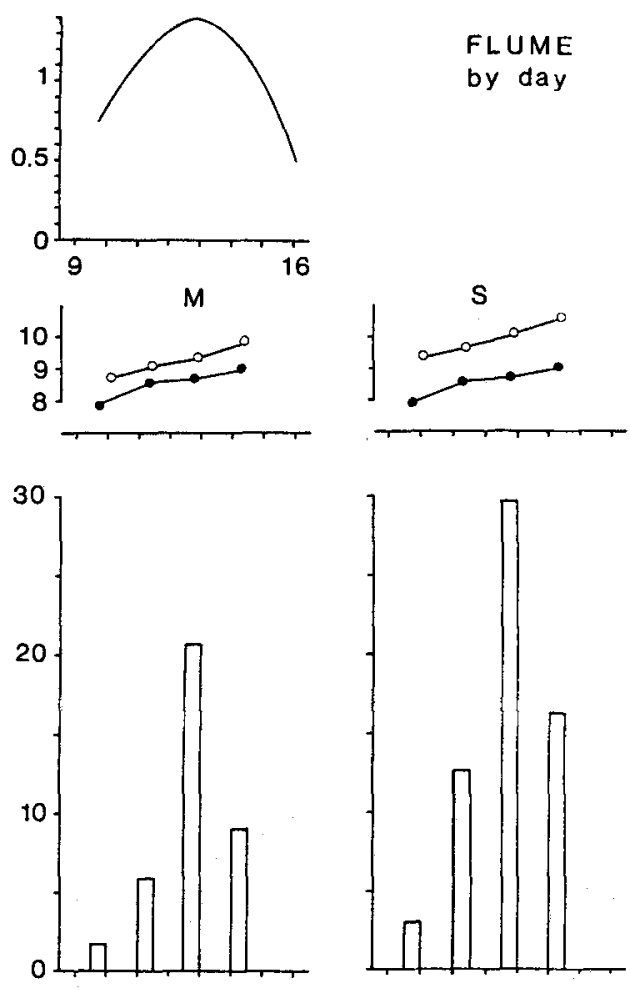

Fig. 2. Oxygen concentrations ( $\bullet$ inflow, $\circ$ outflow) and benthic-pelagic flux rates (positive rates indicate $\mathrm{O}_{2}$ production, negative ones $\mathrm{O}_{2}$ uptake) over mussels (M) and sand (S) in tunnels and the flume during tidal submergence by day. Water depth is given above

\section{Phosphate}

Phosphate discharge by the mussel bed could be measured in the tunnel (outflow concentration $>$ inflow concentration, one sided, $P<0.01, n=9$ ) and in the flume $(P<0.10, n=9)$, whereas rates over sand varied between discharge and uptake (Fig. 7 ) (Table 3). At night, a release of phosphate was evident also in the sand tunnel (Fig. 8).

In the flume, phosphate was released in the mussel lane and in the sand lane during the day. The release seemed to be more pronounced in the mussel lane than in the sand lane but the difference was not statistically significant. At night, there were some high rates of phosphate release in the mussel lane beside smaller, varying rates, whereas the phosphate rates in the sand lane varied strongly between release and uptake. 


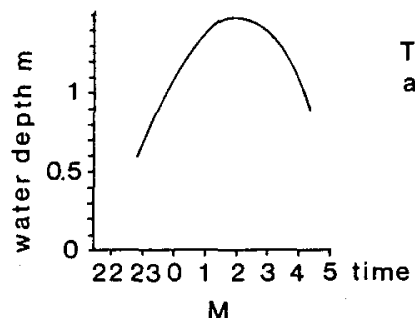

TUNNEL

at night
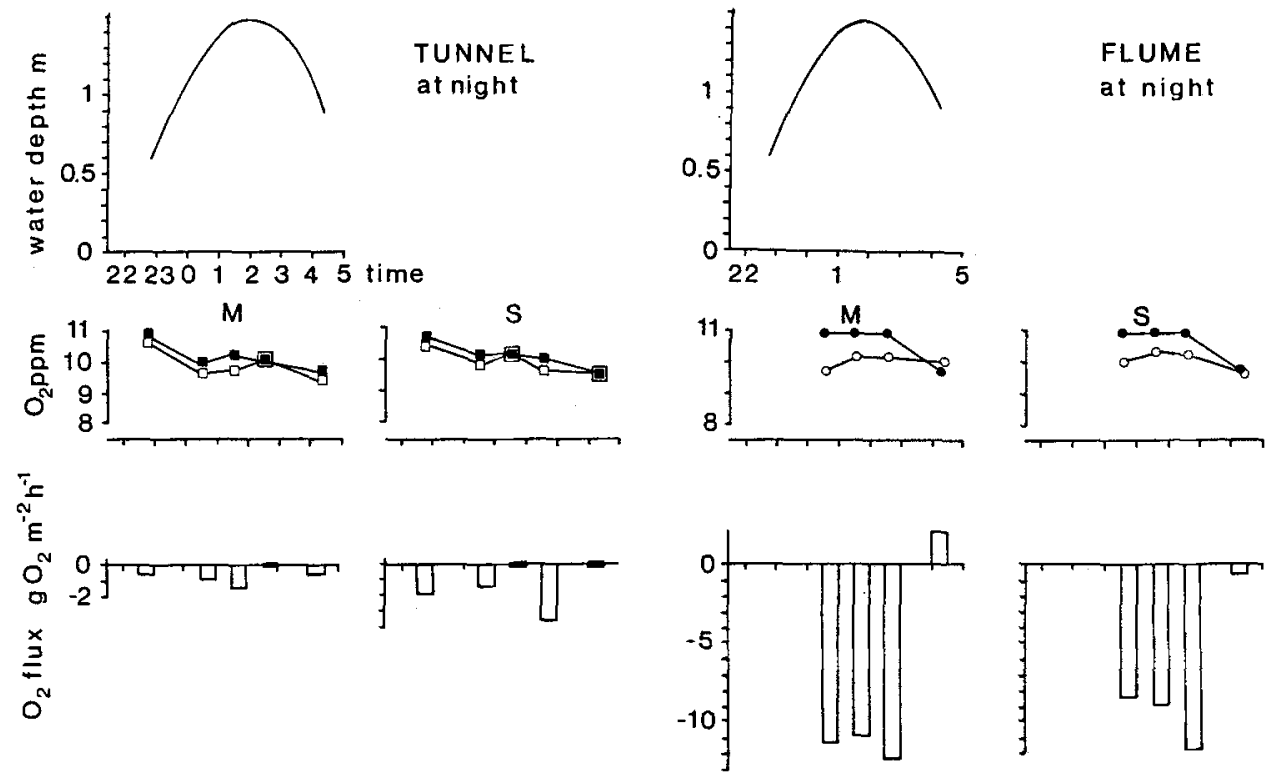

Fig. 3. Oxygen concentrations and flux rates over mussel and sand in tunnels and the flume during tidal submergence at night. For details, see legend of Fig. 2

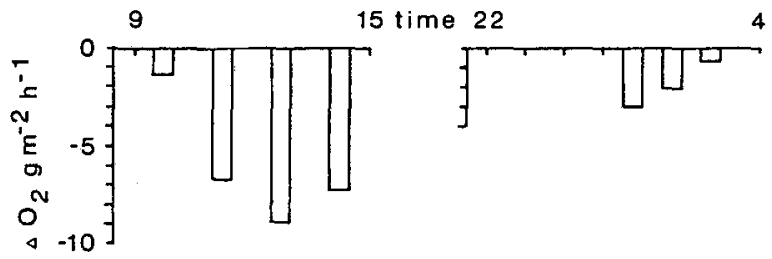

Fig. 4. Differences between oxygen flux rates measured in the mussel lane and in the sand lane of the flume reveal the apparent respiration of the mussel bed. Measurements during the day (on the left) and at night (on the right)

\section{Phytoplankton}

\section{Phytoplankton composition}

The phytoplankton abundance measured during the day (1 June) differed substantially from that measured at night ( 2 to 3 June). A phytoplankton bloom of more than $200 \mu \mathrm{g} \mathrm{Cl}^{-1}$, dominated by Phaeocystis globosa Scherffel, was present by day. $P$. globosa (cell number: up to $17 \times 10^{6}$ cells per liter) formed $76 \pm 11 \%(n=22)$ of total phytoplankton biomass in the inflowing water in tunnels and flume. Abundant diatom species were mainly Rhizosolenia shrubsolei Cleve, $R$. hebetata f. semispina Bailey, Odontella rhombus (Ehrenberg) Kützing, O. sinensis (Greville) Grunow, O. granulata (Roper) Ross. 

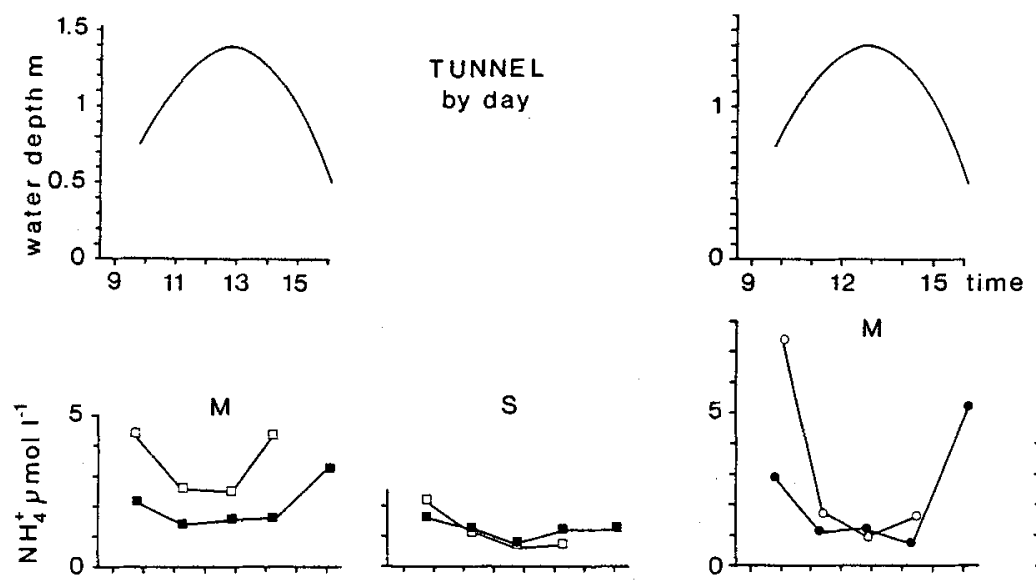

FLUME

by day
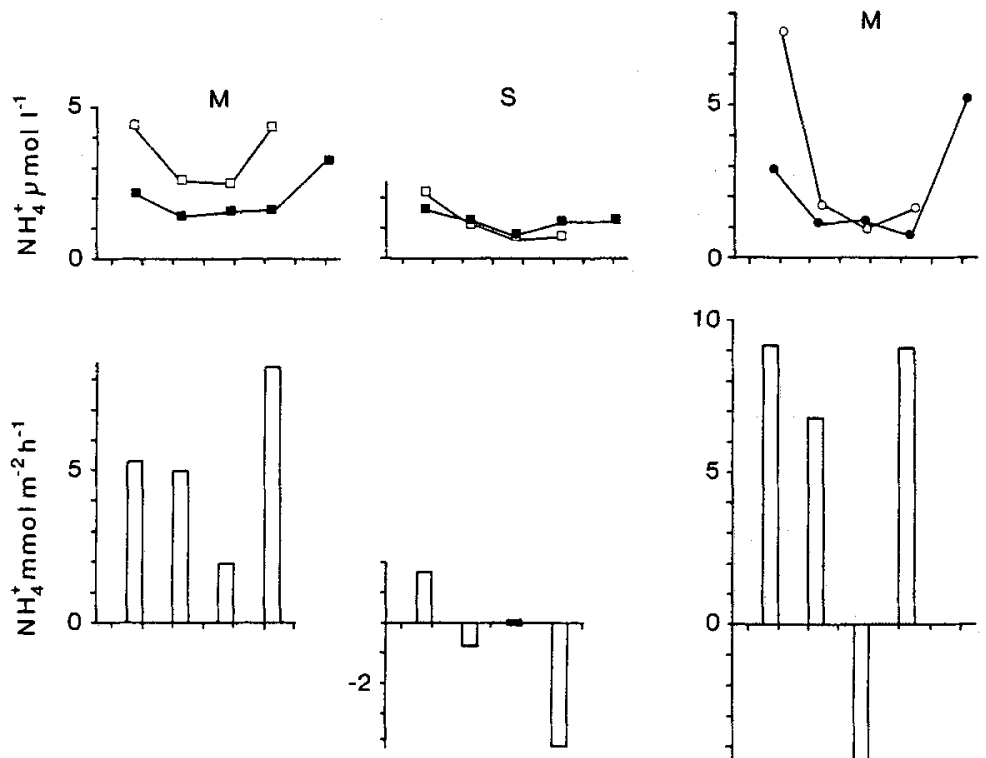

S
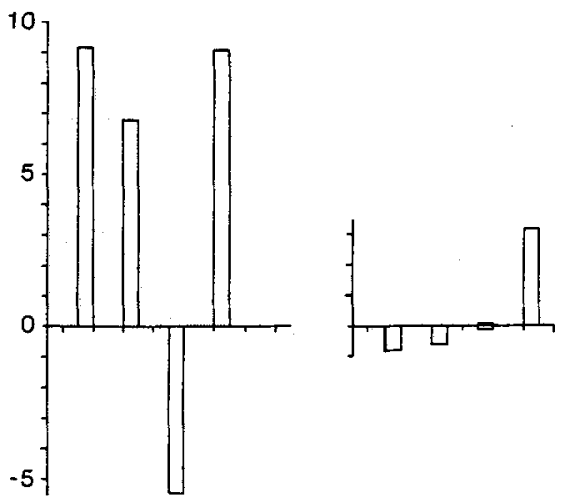

Fig. 5. Ammonium concentrations and flux rates measured in tunnels and the flume during submergence by day. For explanations of symbols, see legend of Fig. 2

During the night, $P$. globosa was no longer present. Some diatom species were still to be found but in low cell numbers (mainly Rhizosolenia shrubsolei, $R$. hebetata f. semispina). Nocturnal phytoplankton concentrations were too low for significant differences to be measured between inflow and outflow of tunnel or flume. Although the time interval between day and night measurements was only $24 \mathrm{~h}$, the water body had changed.

\section{Uptake of phytoplankton}

Uptake of phytoplankton by the mussel bed was evident over mussels in tunnel and flume but it was considerably higher in the flume (Figs 9, 10) (Table 3). Phytoplankton concentrations around high tide were lower in the tunnels than in the flume. In the sand lane of the flume, phytoplankton concentrations remained unchanged between inflow and outflow of the flume, except for the last flux rate which showed a decrease in phytoplankton probably due to sedimentation. 


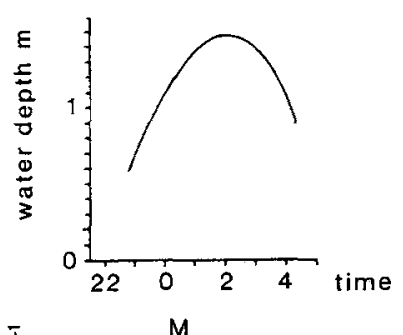

TUNNEL
at night

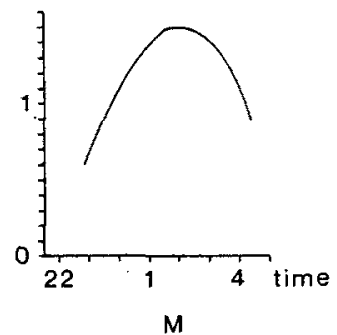

FLUME

at night
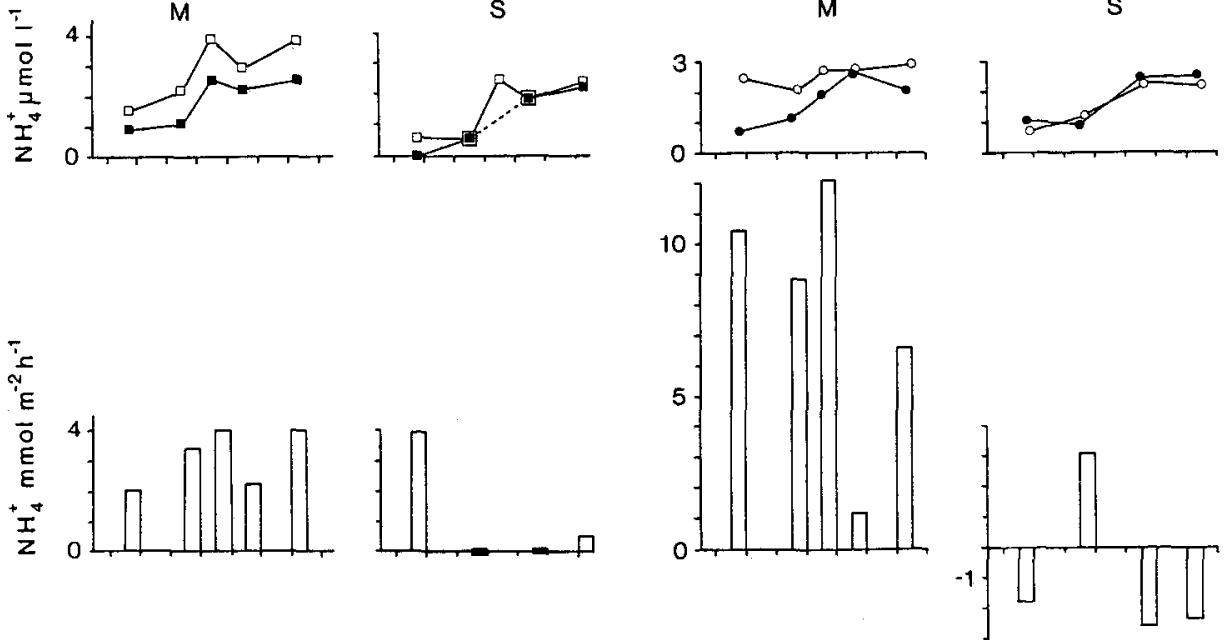

Fig. 6. Ammonium concentrations in the incoming ( $\bullet$ ) and outgoing water (o), and pertinent ammonium flux rates over mussels $(\mathrm{M})$ and sand $(\mathrm{S})$ in tunnels and the flume at night. Positive rates indicate release, negative ones uptake. For details of figure, see legend of Fig. 2
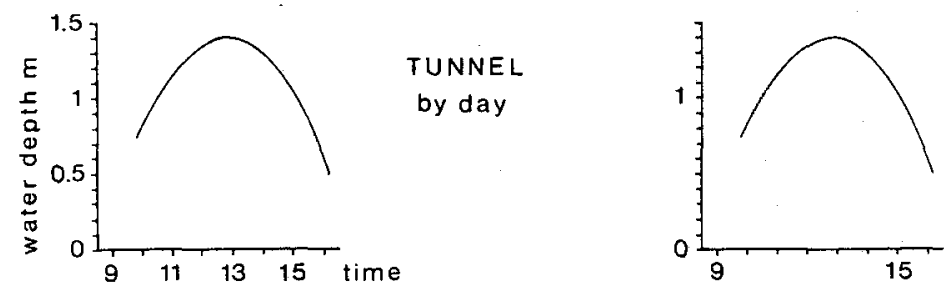

\section{FLUME}

by day
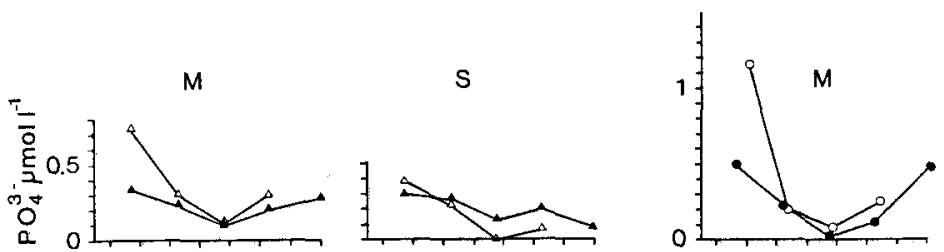

$\mathrm{S}$
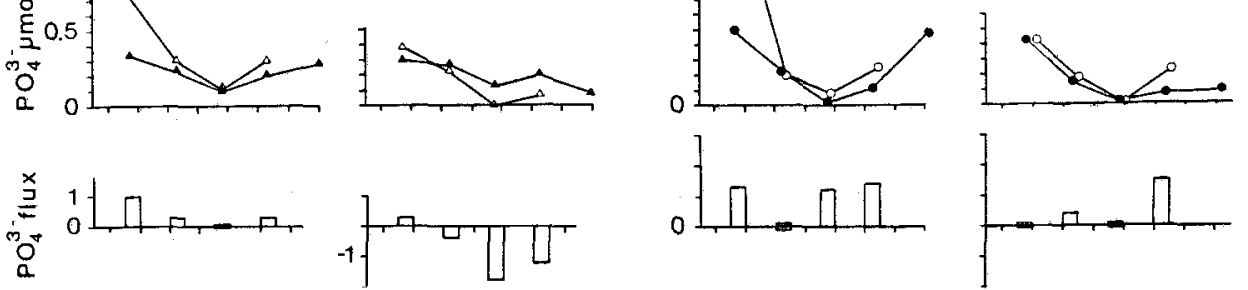

Fig. 7. Inorganic phosphate concentrations and fluxes measured over mussels (M) and sand (S): details according to Fig. 2 

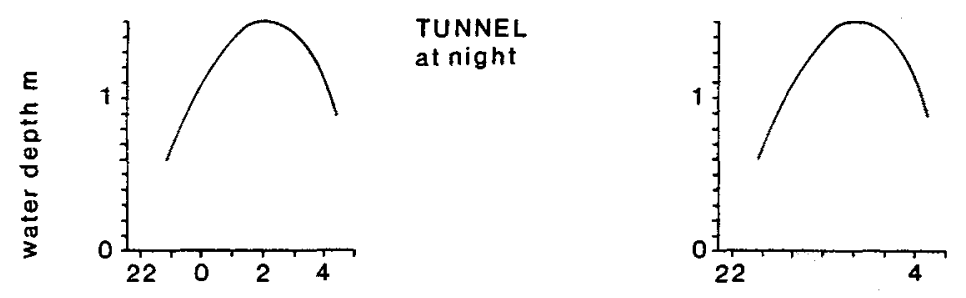

FLUME

at night
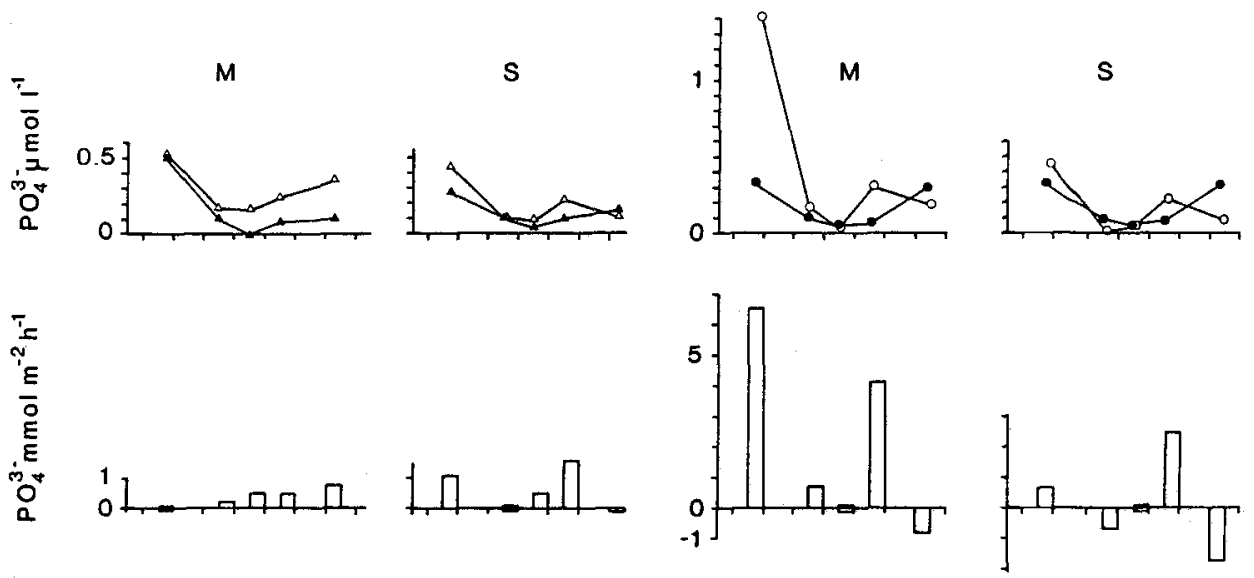

Fig. 8. Inorganic phosphate concentrations and fluxes over mussels (M) and sand (S) in tunnels and the flume in the night of 2 nd to 3rd June; details according to Fig. 2

In the sand tunnel there was a low rate of decrease. At the end of the measurement a high rate of increase of phytoplankton between inflow and outflow occurred.

\section{Clearance rate}

The phytoplankton counts were used to calculate the clearance rates of the mussel beds in tunnel and flume. An analysis of variance showed that the clearance rates calculated from total cell counts, from Phaeocystis globosa counts and from Rhizosolenia shrubsolei counts, were not significantly different $(F=0.92, P>0.05)$. Differences in the clearance rates of tunnel and flume were not significant either $(F=0.01, P>0.05)$. "Clearance rates" calculated for the control tunnel and flume corresponded with sedimentation and resuspension processes. These rates were significantly lower than the clearance rates in the mussel tunnel and flume $(F=13.72, P<0.001)$. The clearance rates based on phytoplankton cell counts are given in Table 2 . The results show that no significant changes in the number of phytoplankton cells occurred in the control tunnel and flume. Thus, it was concluded that sedimentation of phytoplankton in tunnels and flume was generally very low. Considering the average clearance rates of the mussel bed in flume and tunnel and the density of mussels per $\mathrm{m}^{-2}$, an individual clearance rate of $0.491 \mathrm{~h}^{-1}$ was calculated. 


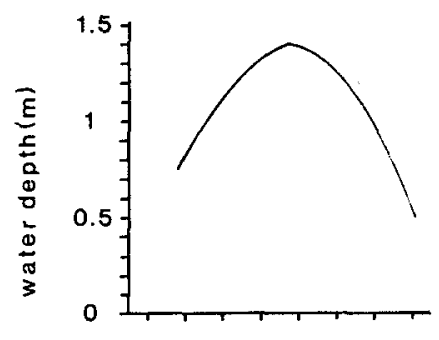

TUNNEL
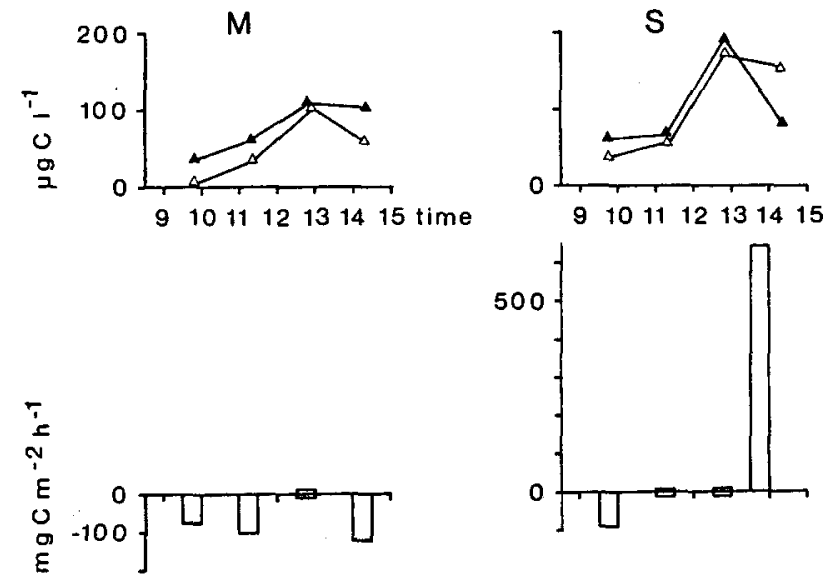

Fig. 9. Phytoplankton biomass ( $\Delta$ inflow, $\Delta$ outflow) calculated from cell counts, and flux rates over mussels $(\mathrm{M})$ and sand $(\mathrm{S})$ in tunnels on 1st June; details according to Fig. 2

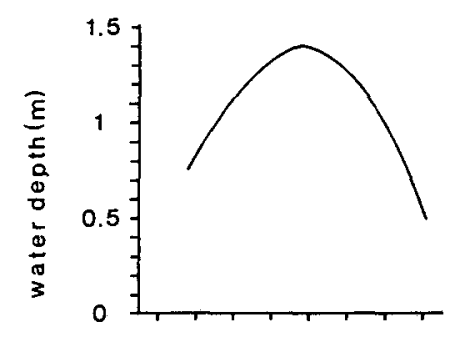

\section{FLUME}
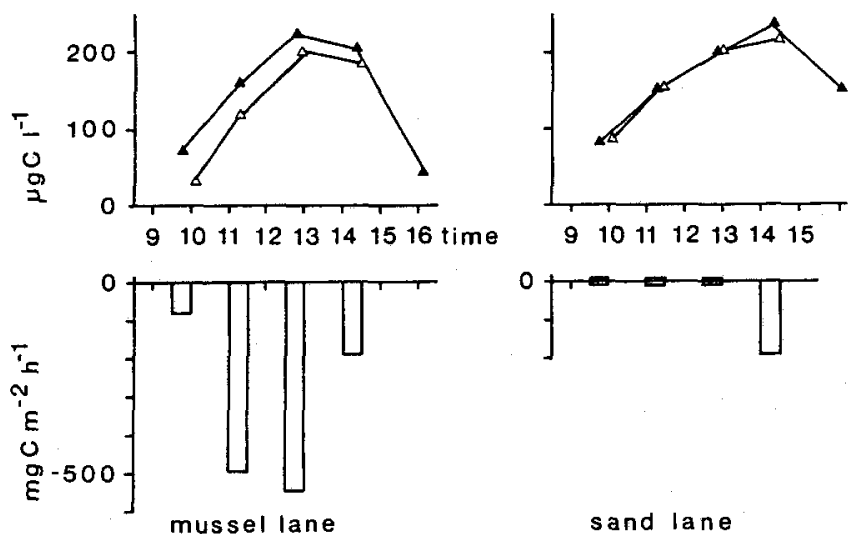

mussel lane

sand lane

Fig. 10. Phytoplankton biomass, and uptake rates of phytoplankton by the mussel bed (M) compared to the rates in the sand lane (S) of the flume on 1st June 
Table 2. Clearance rates calculated from phytoplankton cell counts (means \pm s.e.) in $\mathrm{m}^{3} \mathrm{~m}^{-2} \mathrm{~h}^{-1}$

\begin{tabular}{|lr|}
\hline Control flume & $-0.4 \pm 0.16$ \\
Mussel flume & $2.9 \pm 1.12$ \\
Control tunnel & $-0.9 \pm 2.06$ \\
Mussel tunnel & $2.1 \pm 1.01$ \\
\hline
\end{tabular}

\section{Particulate organic carbon}

In the tidal waters over the mussel bed, POC concentrations ranged between 0.3 and $1.5 \mathrm{mg} \mathrm{C} \mathrm{l}^{-1}$. During daytime, the concentrations of POC in the inflow of tunnels and flume increased with the rising tide and decreased with the falling tide (Fig. 11). During the night, the POC concentrations showed only slight changes during the tidal cycle (Fig. 12).

Flux rates of POC as measured by the two measuring devices differed far more than the day and night measurements (uptake in mussel flume lane $>$ uptake in mussel tunnel, Wilcoxon matched pairs signed rank test, $P<0.05, \mathrm{n}=8$ ) (Table 3). In the mussel lane of the flume, POC was mainly taken up despite the release at the end of the ebb tide (inflow concentration $>$ outflow concentration, same test, $P<0.10$, one sided, $n=8$ ). The

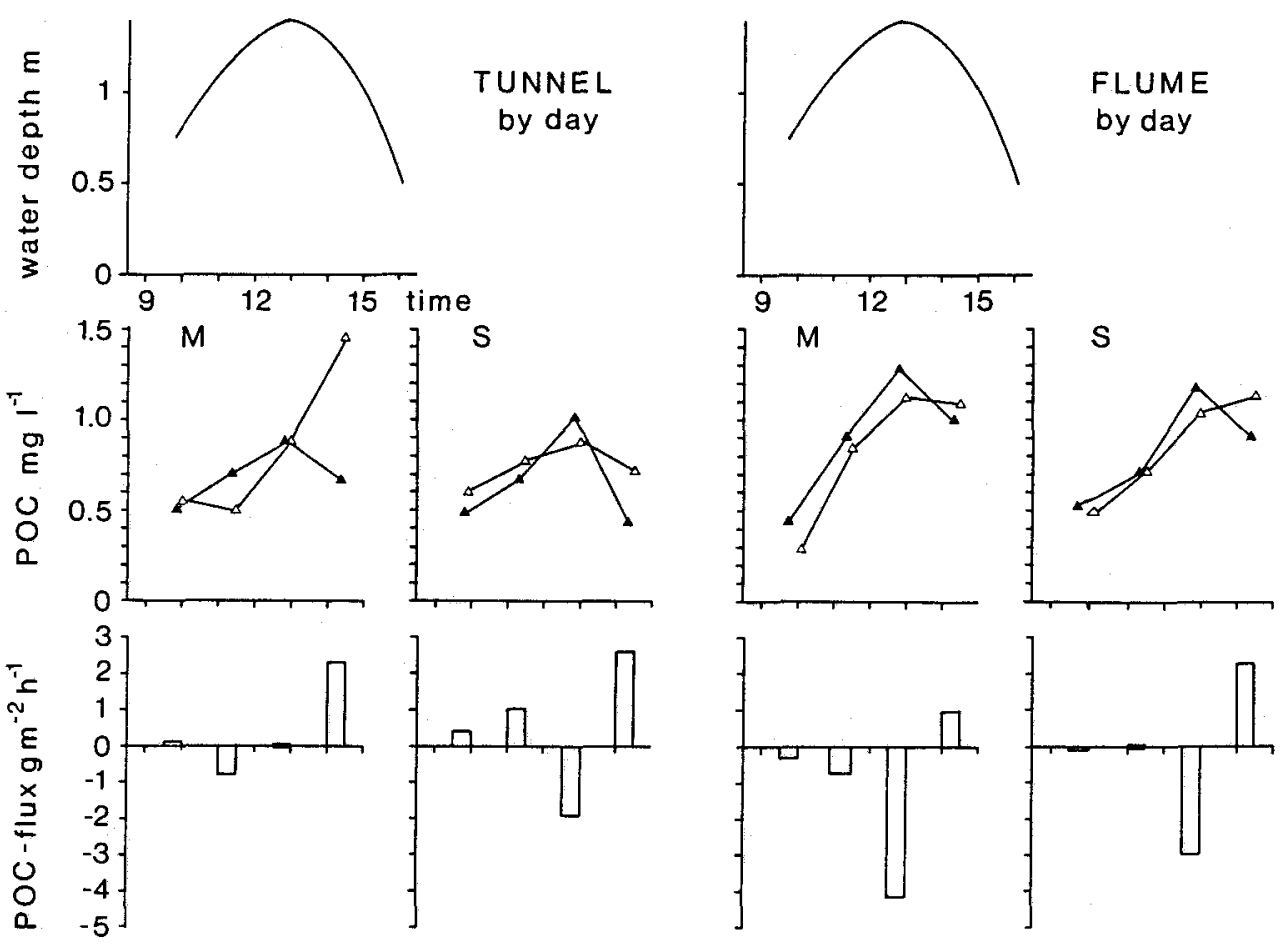

Fig. 11. POC concentrations and fluxes measured synchronously in tunnels and the flume on 1st June; details of the figure according to Fig. 2 


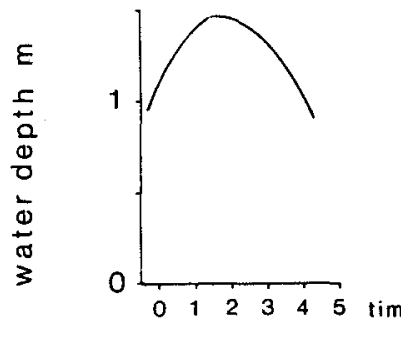

$\mathrm{M}$
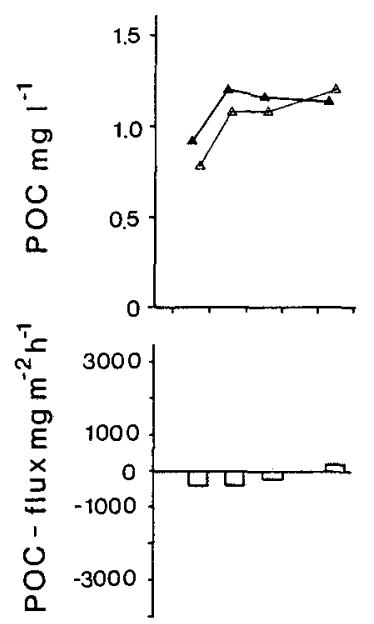

TUNNEL at night
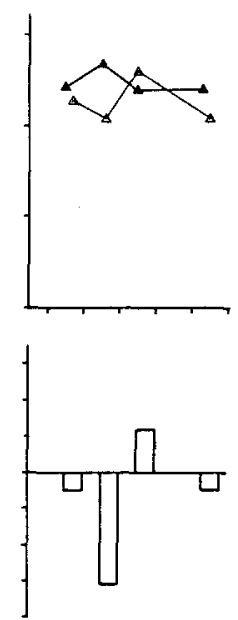

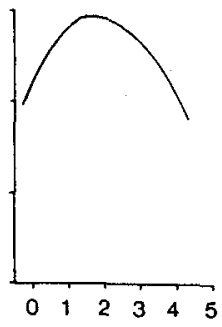

$\mathrm{M}$
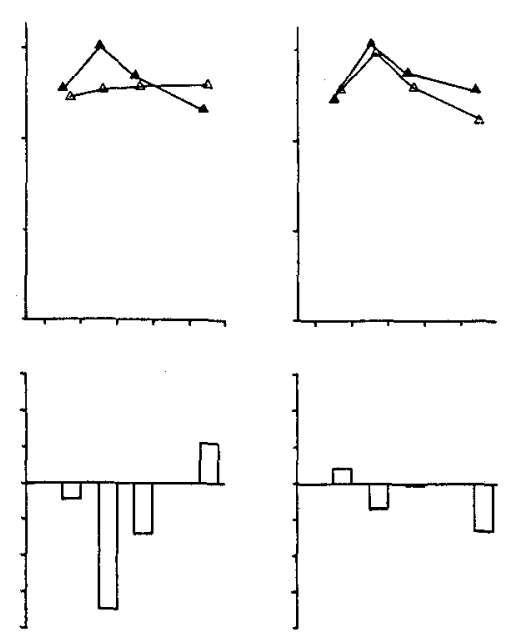

FLUME

at night

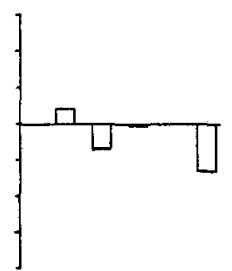

Fig. 12. Concentrations and flux rates of POC over mussels (M) and sand (S) in tunnels and the flume in the night of 2nd to 3rd June

mussel tunnel showed an irregular flux rate pattern of POC. At the end of the tidal cycle an extraordinary high export of POC was measured.

In the sand, both uptake and release of POC occurred. No discernible pattern between tunnel and flume was apparent.

\section{Particulate nitrogen}

Concentrations of PN in the inflowing water varied between 36 and $207 \mu \mathrm{g} \mathrm{l}^{-1}$ (Figs 13, 14). PN content was low in the water entering the flume and increased with rising water level to a maximum at high tide by day and at night. During ebb tide, concentrations decreased. At the mussel sites, flux rate patterns of PN resembled those of POC values (same test, one sided, inflow concentr. $>$ outflow concentr.: flume: $\mathrm{P}<0.05, \mathrm{n}=8$, tunnel: $\mathrm{P}<0.10, \mathrm{n}=8$ ). Uptake rates in the mussel tunnel were lower than those in the mussel lane of the flume (same test, two sided, $\mathrm{P}<0.10, \mathrm{n}=8$ ) (Table 3). Similar to the POC flux, a notable PN release was measured in the mussel tunnel at the end of the tidal cycle by day. Flux rates over the sand areas showed irregular patterns. In the sand lane of the flume, uptake rates predominated during the day, but they were distinctly lower than 

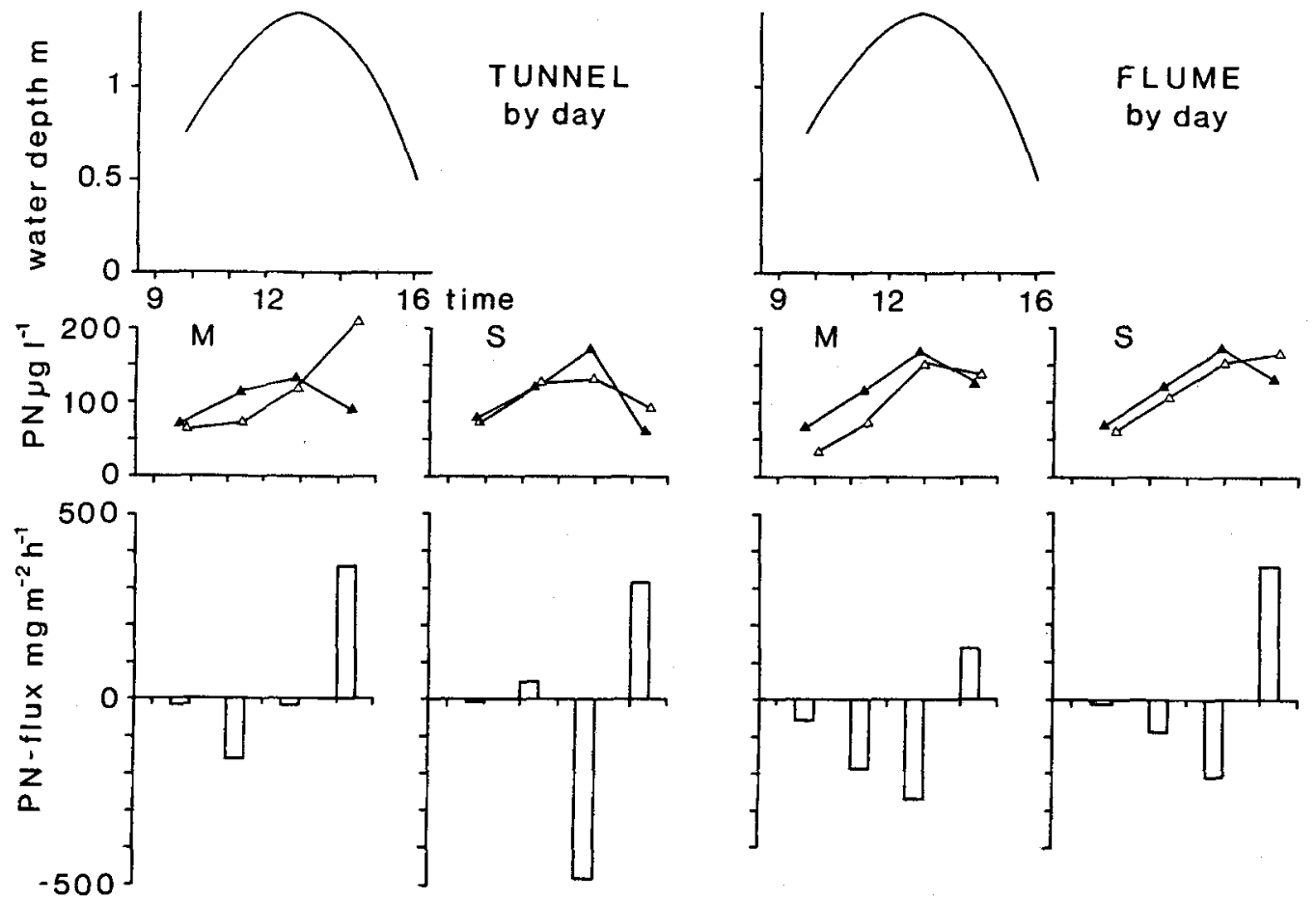

Fig. 13. Concentrations of particulate nitrogen (PN) and flux rates measured over mussels (M) and sand $(S)$ in tunnels and the flume by day
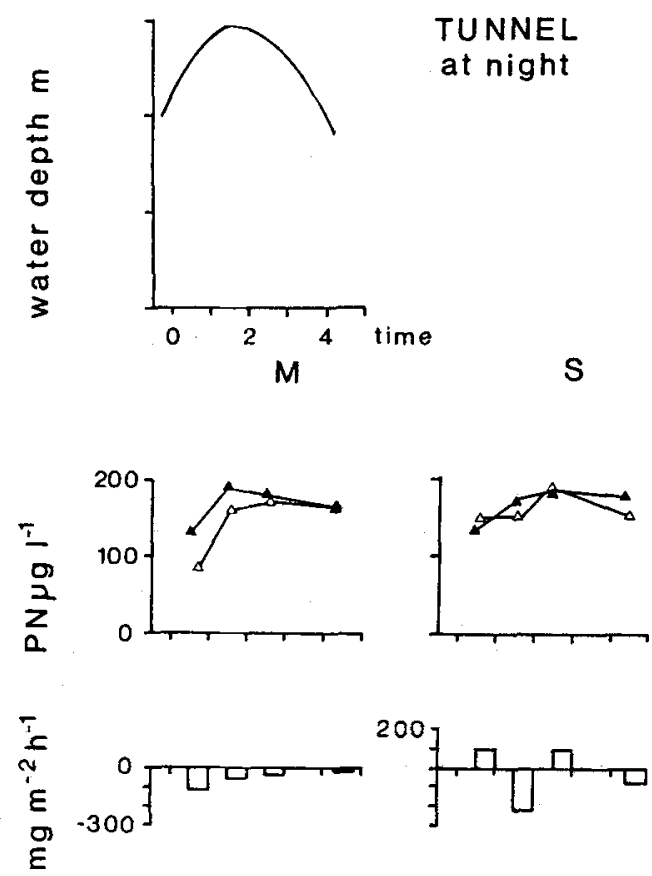

TUNNEL at night

S

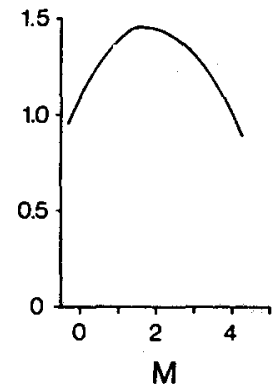

FLUME at night

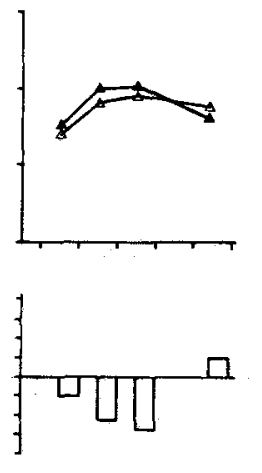

S
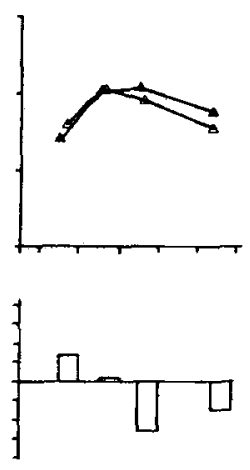

Fig. 14. Corresponding measurement of PN concentrations and flux rates at night (2nd to 3rd June) 
Table 3. Flux rates measured in mussel- and sand-tunnel and in mussel- and sand-lane of the flume. Oxygen: $\mathrm{g} \mathrm{m}^{-2} \mathrm{~h}^{-1}$; nutrients: mmol m $\mathrm{m}^{-2} \mathrm{~h}^{-1}$; phytoplankton-C, PN, POC: $\mathrm{mg} \mathrm{m}^{-2} \mathrm{~h}^{-1}$

\begin{tabular}{|c|c|c|c|c|c|}
\hline \multirow[t]{2}{*}{ Parameter } & \multirow[t]{2}{*}{ Time } & \multicolumn{2}{|c|}{ Tunnel } & \multicolumn{2}{|c|}{ Flume } \\
\hline & & Mussel & Sand & Mussel & Sand \\
\hline Oxygen & $\begin{array}{r}9: 45 \\
11: 20 \\
12: 50 \\
14: 20 \\
22: 45 \\
0: 32 \\
1: 28 \\
2: 31 \\
4: 21\end{array}$ & $\begin{array}{c}-0.95 \\
-0.80 \\
+0.60 \\
-1.81 \\
-0.60 \\
-0.90 \\
-1.51 \\
0 \\
-0.60\end{array}$ & $\begin{array}{c}0 \\
0 \\
+4.07 \\
+0.46 \\
-1.92 \\
-1.43 \\
0 \\
-3.58 \\
0\end{array}$ & $\begin{array}{r}+1.68 \\
+5.90 \\
+20.72 \\
+8.95 \\
- \\
-11.44 \\
-10.95 \\
-12.43 \\
+2.08\end{array}$ & $\begin{array}{r}+3.03 \\
+12.63 \\
+29.61 \\
+16.25 \\
- \\
-8.44 \\
-8.88 \\
-11.76 \\
-0.62\end{array}$ \\
\hline Ammonium & $\begin{array}{r}9: 45 \\
11: 20 \\
12: 50 \\
14: 20 \\
22: 45 \\
0: 32 \\
1: 28 \\
2: 31 \\
4: 21\end{array}$ & $\begin{array}{l}+5.29 \\
+5.02 \\
+1.97 \\
+8.43 \\
+2.05 \\
+3.40 \\
+4.01 \\
+2.20 \\
+4.01\end{array}$ & $\begin{array}{c}+1.70 \\
-0.74 \\
0 \\
-4.02 \\
+3.90 \\
0 \\
- \\
0 \\
+0.52\end{array}$ & $\begin{array}{r}+9.14 \\
+6.82 \\
-5.52 \\
+9.05 \\
+10.44 \\
+8.85 \\
+12.12 \\
+1.18 \\
+6.62\end{array}$ & $\begin{array}{c}-0.88 \\
-0.62 \\
0 \\
+3.19 \\
-1.80 \\
+3.12 \\
- \\
-2.62 \\
-2.37\end{array}$ \\
\hline Phosphate & $\begin{array}{r}9: 45 \\
11: 20 \\
12: 50 \\
14: 20 \\
22: 45 \\
0: 32 \\
1: 28 \\
2: 31 \\
4: 21\end{array}$ & $\begin{array}{c}+0.98 \\
+0.28 \\
0 \\
+0.30 \\
0 \\
+0.24 \\
+0.48 \\
+0.48 \\
+0.75\end{array}$ & $\begin{array}{c}+0.33 \\
-0.37 \\
-1.76 \\
-1.19 \\
+1.09 \\
0 \\
+0.52 \\
+1.55 \\
-0.14\end{array}$ & $\begin{array}{c}+1.33 \\
0 \\
+1.23 \\
+1.41 \\
+6.54 \\
+0.69 \\
0 \\
+4.15 \\
-0.78\end{array}$ & $\begin{array}{c}0 \\
+0.40 \\
0 \\
+1.54 \\
+0.72 \\
-0.68 \\
0 \\
+2.47 \\
-1.69\end{array}$ \\
\hline $\begin{array}{l}\text { Phytoplankton } \\
\text { Carbon }\end{array}$ & $\begin{array}{r}9: 45 \\
11: 20 \\
12: 51 \\
14: 21\end{array}$ & $\begin{array}{c}-74.67 \\
-100.65 \\
0 \\
-119.06\end{array}$ & $\begin{array}{c}-87.84 \\
0 \\
0 \\
+646.00\end{array}$ & $\begin{array}{r}-80.10 \\
-495.46 \\
-546.12 \\
-189.65\end{array}$ & $\begin{array}{c}0 \\
0 \\
0 \\
-191.54\end{array}$ \\
\hline PN & $\begin{array}{r}9: 45 \\
11: 20 \\
12: 51 \\
14: 20 \\
0: 32 \\
1: 28 \\
2: 31 \\
4: 21\end{array}$ & $\begin{array}{r}-14.6 \\
-160.4 \\
-18.9 \\
+360.1 \\
-122.3 \\
-62.5 \\
-41.4 \\
-19.6\end{array}$ & $\begin{array}{r}-8.3 \\
+48.7 \\
-485.5 \\
+314.6 \\
+107.7 \\
-225.7 \\
+89.0 \\
-79.7\end{array}$ & $\begin{array}{r}-61.3 \\
-188.6 \\
-270.4 \\
+139.2 \\
-97.7 \\
-227.1 \\
-274.3 \\
+107.6\end{array}$ & $\begin{array}{r}-6.8 \\
-90.2 \\
-210.3 \\
+362.2 \\
+141.8 \\
+17.2 \\
-270.0 \\
-164.8\end{array}$ \\
\hline POC & $\begin{array}{r}9: 45 \\
11: 20 \\
12: 50 \\
14: 20 \\
0: 32 \\
1: 28 \\
2: 31 \\
4: 21\end{array}$ & $\begin{array}{r}+88.8 \\
-808.9 \\
0 \\
+2348.1 \\
-376.0 \\
-359.0 \\
-212.0 \\
+195.0\end{array}$ & $\begin{array}{r}+442.7 \\
+1047.4 \\
-1938.8 \\
+2603.7 \\
-542.0 \\
-3123.0 \\
+1268.0 \\
-545.0\end{array}$ & $\begin{array}{r}-287.0 \\
-769.3 \\
-4151.2 \\
+932.6 \\
-445.6 \\
-3515.5 \\
-1394.2 \\
+1130.7\end{array}$ & $\begin{array}{r}-52.5 \\
0 \\
-3002.3 \\
+2310.3 \\
+416.3 \\
-713.8 \\
-21.8 \\
-1331.0\end{array}$ \\
\hline
\end{tabular}


those measured in the mussel lane. In the sand tunnel, uptake and release of PN alternated. Exchange rates measured in the mussel tunnel and those measured in the sand tunnel were in the same order of magnitude. The measurements showed a net import of particulate material into the mussel bed during a tidal cycle. When the upper part of the water column was excluded by the tunnel, lower exchange rates were measured. However, an uptake of PN was higher in the mussel bed than in the sand area.

\section{DISCUSSION}

On the mussel bed, tunnel and flume showed corresponding tendencies in nutrient fluxes. Flux rate measurements of particulate material, phytoplankton and oxygen differed for tunnel and flume over mussels. Differences in flux rates occur, because water column processes had an impact on the benthic-pelagic exchange.

Fluxes measured in sandy areas with tunnel and flume were mostly irregular or showed an opposite tendency compared to those measured on the mussel bed.

A quantitative comparison of mussel bed and sand areas with regard to the material fluxes is only possible within the context of the special features of the measuring devices.

\section{Oxygen}

Tunnels and flume revealed different oxygen fluxes. Water column processes as primary productivity during the day experiment and pelagic oxygen consumption during the night led to high background flux values in the control lane (Table 3).

In the tunnels, these oxygen fluxes were lower, because only the lowest part (up to $50 \mathrm{~cm}$ ) of the water column was included and consequently a lower phytoplankton biomass $\mathrm{m}^{-2}$ as well as a lower particle mass $\mathrm{m}^{-2}$ was found. The benthic oxygen fluxes in the mussel lane of the flume became visible after subtraction of the background values of the control (Fig. 4). Thus, the values found in the flume were in the upper range and those measured in the mussel tunnel were in the lower range of data from literature (Dankers et al., 1989; Asmus et al., 1990). The net benthic oxygen fluxes showed a similar tendency in tunnels as well as in flumes, but the height of the oxygen fluxes and the oxygen budget differed due to exclusion or enclosure of the total water column.

\section{Nutrients}

No significant difference between the nutrient fluxes of both tunnels and flume was found. The nutrient discharge seemed to occur mainly at the sediment water interface and is independent of the total water column.

The high release of ammonium by the mussel bed is typical of filter-feeder assemblages (Nixon et al., 1976; Doering et al., 1987; Dame \& Dankers, 1988; Dame et al., 1989; Prins \& Smaal, 1990; Asmus et al. 1990). The excretion by mussels and the release by bacteria from the organically rich sediment are sources of this intense recycling of nitrogen in the mussel bed compared to the sandy area with much smaller ammonium exchange rates.

There is also a slightly higher discharge of inorganic phosphate by the mussel bed than by the sandy area (Table 3), with the exception of the tunnel at night. Phosphate is 
excreted by mussels (Kautsky \& Wallentinus, 1980), and the porewater of the mussel bed as well as of the sand area were rich in phosphate (Asmus, unpubl.). In addition to biological processes, adsorption under oxic conditions and desorption under anoxic conditions play a major role in the regulation of bentho-pelagic phosphate fluxes (Balzer et al., 1983).

\section{Phytoplankton}

Phytoplankton uptake by the mussel bed was evident in tunnel and flume in comparison to the control areas. This uptake was higher in the flume than in the tunnel because more phytoplankton was available to the mussels in the flume. In earlier tunnel and flume measurements, the uptake of phytoplankton by mussel beds was linearly correlated with input concentrations (Prins \& Smaal, 1990; Asmus \& Asmus, 1991). The inflow concentrations in both tunnels and flume lanes revealed the classical bell-shaped curve of phytoplankton input from deeper waters. At higher water levels, phytoplankton concentrations in tunnels were lower than in the flume. The near-bottom water entering the tunnels may be more strongly influenced by benthic communities of the entrance region than the inflowing water of the flume because turbulent mixing and enclosure of the whole water column diminishes this effect.

\section{Clearance rate}

Clearance rates were similar in both systems (tunnels and flume). Thompson \& Bayne (1974) determined for clearance rates of Mytilus edulis an allometric relationship between dry flesh weight and clearance rate $\mathrm{c}=1.944 \mathrm{w}^{0.39}$ at $15^{\circ} \mathrm{C}$. For the mussels in tunnel and flume, mean individual dry flesh weight 0.396 , corresponding to a total weight of $0.504 \mathrm{~g} \mathrm{AFDW}$, a clearance rate of $1.35 \mathrm{l} \mathrm{h}^{-1}$ was calculated. This is more than the average values found in the tunnel $\left(0.41 \mathrm{l} \mathrm{h}^{-1}\right)$ and flume $\left(0571 \mathrm{~h}^{-1}\right)\left(\right.$ mean $\left.0.491 \mathrm{~h}^{-1}\right)$.

Mussels show reduced clearance rates and food consumption at high concentrations of Phaeocystis according to Wolters (1989). However, in a one-lane flume a reduction of $P$. globosa biomass by a mussel bed was measured (Asmus \& Asmus, 1991) and is now confirmed with the aid of the control lane in the flume and with the sand tunnel compared to the mussel tunnel.

\section{Particulate matter}

POC- and PN-fluxes showed similar tendencies, but the rates measured by the different measuring devices varied. Uptake of POC and PN by mussel filtration was higher in the flume than in the tunnel. This difference reveals the importance of the total water column for the particle exchange between benthos and tidal water. In the tunnel, only the particulate matter of the near bottom water is subjected to filtration by mussels.

In the flume, the total water column is included, and sedimentation of particles rich in phytoplankton from the upper parts of the water column may lead to a replenishment of food particles in the bottom water impoverished by mussel filtration.

Uptake of phytoplankton by the mussel bed in the flume was up to 2 times higher than in the tunnel.

In the sand area, the fluxes showed an irregular pattern, but the rates in the flume and tunnels were of a similar order of magnitude. 
Fluxes of particulate matter are determined by different counteracting processes such as sedimentation and resuspension. Over a mussel bed, filtration and defecation occur in addition. Sedimentation of particles is predominately determined by the water movement and should be similar in both areas, whether mussel bed or sand area; and, indeed, no differences in sedimentation were observed in these two areas. Resuspension of particles may depend upon the type of sediment. Faecal material deposited between mussels may easily be resuspended. Filtration and defecation are high in the mussel bed area and should be mainly responsible for the differences between mussel bed and sand area with regard to fluxes of particulate matter.

Mussel beds enlarge the sink function of a tidal flat by filtration (Verwey, 1952; Haven \& Morales Alamo, 1966; Dame et al., 1980; Doering et al., 1986). However, this may depend on the weather situation. During both tidal cycles, the wind speed was low and the water calm. Stronger winds and turbulence may cause mussel beds to become a source of particles (Asmus et al., 1990).

\section{CONCLUSIONS}

Material flux measurements in tunnels and flumes gave different results in most of the compared parameters. Water column processes intensify the vertical material fluxes over a mussel bed. Different results on the oxygen budget over a mussel bed may be attained when water column processes are included. Tunnel measurements indicate the minimum material flux of a benthic assemblage. Tunnels are applicable in deeper waters and their installation is more flexible and needs less time. The design of tunnels must be adapted carefully to the current regime, to avoid trapping and sedimentation effects. Flumes can only be set up in shallow waters with a stable current regime. They include the total water column and allow the measurement of exchange under more natural conditions. It is therefore of general importance to evaluate the flow-through methodology concerned with estimating benthic-pelagic material fluxes.

In the light of the differences and similarities between the two methods, the conclusions concerning the ecological role of mussel beds are not likely to be different whether tunnels or flumes are used.

Acknowledgements. We are grateful for help during the field measurements to B. Ipsen, A. Pouwer, P. van Leeuwen and K. Runze. C. Berger kindly revised the English text. This study was supported by the Deutsche Forschungsgemeinschaft ( $R E$ 425/6-3) and by the Bundesministerium für Forschung und Technologie (Ökosystemforschung Wattenmeer, SWAP, publication No. 35).

\section{LITERATURE CITED}

Asmus, H., Asmus, R. M. \& Reise, K., 1990. Exchange processes in an intertidal mussel bed: a Syltflume study in the Wadden Sea. - Ber. Biol. Anst. Helgoland 6, 1-79.

Asmus, H. \& Asmus, R. M., 1990. Trophic relationships in tidal flat areas: to what extent are tidal flats dependent on imported food? - Neth. J. Sea Res. 27, 93-99.

Asmus, R. M. \& Asmus, H., 1991. Mussel beds: limiting or promoting phytoplankton? - J. exp. mar. Biol. Ecol. 148, 215-232.

Balzer, W., Grasshoff, K., Dieckmann, P., Haardt, H. \& Petersohn, U., 1983. Redoxturnover at the sediment/water interface studied in a large bell jar system. - Oceanol. Acta 6, 337-344.

Bayne, B. L., 1976. Marine mussels: their ecology and physiology., Univ. Press, Cambridge, 506 pp. 
Coughlan, J., 1969. The estimation of filtering rate from the clearance of suspension. - Mar. Biol. 2, 356-358.

Dame, R. F., Zingmark, R. G., Stevenson, L. H. \& Nelson, D., 1980. Filter feeder coupling between the estuarine water column and benthic subsystems. In: Estuarine perspectives. Ed. by V. C. Kennedy. Acad. Press, New York, 521-526.

Dame, R. F., Zingmark, R. G. \& Haskin, E., 1984. Oyster reefs as processors of estuarine materials. J. exp. mar. Biol. Ecol. 83, 239-247.

Dame, R. F. \& Dankers, N., 1988. Uptake and release of materials by a Wadden Sea mussel bed. - J. exp. mar. Biol. Ecol. 118, 207-216.

Dame, R. F., Spurrier, J. D. \& Wolaver, T. G., 1989. Carbon, nitrogen and phosphorus processing by an oyster reef. - Mar. Ecol. Prog. Ser. 54, 249-256.

Dame, R., Dankers, N., Prins, T., Jongsma, H. \& Smaal, A., 1991. The influence of mussel beds on nutrients in the Western Wadden Sea and Eastern Scheldt estuaries. - Estuaries 14, 130-138.

Dankers, N., Dame, R. \& Kersting, K., 1989. The oxygen consumption of mussel beds in the Dutch Wadden Sea. - Scientia mar. 53, 473-476.

Doering, P. H., Oviatt, C. A. \& Kelly, J. R., 1986. The effects of the filter-feeding clam Mercenaria mercenaria on carbon cycling in experimental marine mesocosms. - J. mar. Res. 44, 839-861.

Doering, P. H., Kelly, J. R., Oviatt, C. A. \& Sowers, T., 1987. Effect of the hard clam Mercenaria mercenaria on benthic fluxes of inorganic nutrients and gases. - Mar. Biol. 94, 377-383.

Edler, L., 1979. Recommendations on methods for marine biological studies in the Baltic - phytoplankton and chlorophyll. - Baltic mar. Biol. Publ. 5, 1-38.

Grasshoff, K., Ehrhardt, M. \& Kremling, K., 1983. Methods of seawater analysis. Verl. Chemie, Weinheim, $419 \mathrm{pp}$.

Haven, D. \& Morales-Alamo, R., 1966. Aspects of biodeposition by oysters and other invertebrate filter feeders. - Limnol. Oceanogr. 1, 487-498.

Kautsky, N. \& Wallentinus, I., 1980. Nutrient release from a Baltic Mytilus-red algal community and its role in benthic and pelagic productivity. - Ophelia (Suppl.) 1, 17-30.

Murphy, R. C. \& Kremer, J. N., 1985. Bivalve contribution to benthic metabolism in a California lagoon. - Estuaries 8, 330-341.

Nixon, S. W., Oviatt, C. A., Rogers, C. \& Taylor, K., 1971. Mass and metabolism of a mussel bed. Oecologia $8,21-30$.

Nixon, S. W., Oviatt, C. A., Garber, J. \& Lee, V., 1976. Diel metabolism and nutrient dynamics in a salt marsh embayment. - Ecology 57, 740-750.

Prins, T. C. \& Smaal, A. C., 1990. Benthic-pelagic coupling: the release of inorganic nutrients by an intertidal bed of Mytilus edulis. In: Trophic relationships in the marine environment. Ed. by $M$. Barnes \& R. N. Gibson. Univ. Press, Aberdeen, 89-103.

Thompson, R. J. \& Bayne, B. L., 1974. Some relationships between growth, metabolism and food in the mussel Mytilus edulis. - Mar. Biol. 27, 317-326.

UNESCO, 1973. International Oceanographic Tables. UNESCO, Paris, 2, 1-141.

Verwey, J., 1952. On the ecology of distribution of cockle and mussel in the Dutch Wadden Sea, their role in sedimentation and the source of their food supply - a short review of the feeding behaviour of bivalve molluscs. - Archs néerl. Zool. 10, 171-239.

Wagner, R., 1979a. Die Praxis der Bestimmung des biochemischen Sauerstoffbedarfs - Ergebnisse einer Umfrage. - Vom Wasser 52, 253-287.

Wagner, R., 1979b. Berichtigung und Ergänzung zur Veröffentlichung: Die Praxis der Bestimmung des biochemischen Sauerstoffbedarfs - Ergebnisse einer Umfrage. - Vom Wasser 53, 283-285.

Wolaver, T., Whiting, G., Kjerfve, B., Spurrier, J., McKellar, H., Dame, R., Chrzanowski, T., Zingmark, R. \& Williams, T., 1985. The flume design - a methodology for evaluating material fluxes between a vegetated salt marsh and the adjacent tidal creek. - J. exp. mar. Biol. Ecol. 91 . 281-291.

Wolters, E., 1989. Het effect van aanwezighed van Phaeocystis pouchetii in het seston op het energiebudget van de mossel Mytilus edulis. Dienst Getijdewateren, Rijkswaterstaat, Middelburg. (GWAO - 88.1343) 